\title{
Acetylcholine release and inhibitory interneuron activity in hippocampal CA1
}

\author{
A. Rory McQuiston * \\ Department of Anatomy and Neurobiology, Virginia Commonwealth University, Richmond, VA, USA
}

\section{Edited by:}

Sukumar Vijayaraghavan, University of Colorado Health Science Center, USA

\section{Reviewed by:}

Scott Thompson, University of

Maryland School of Medicine, USA

Qian Sun, Columbia University, USA

${ }^{*}$ Correspondence:

A. Rory McQuiston, Department of Anatomy and Neurobiology, Virginia Commonwealth University, Sanger Hall 9-060, 1101 E. Marshall St. Box 980709, Richmond, VA 23298, USA

e-mail: amcquiston@vcu.edu
Acetylcholine release in the central nervous system (CNS) has an important role in attention, recall, and memory formation. One region influenced by acetylcholine is the hippocampus, which receives inputs from the medial septum and diagonal band of Broca complex (MS/DBB). Release of acetylcholine from the MS/DBB can directly affect several elements of the hippocampus including glutamatergic and GABAergic neurons, presynaptic terminals, postsynaptic receptors, and astrocytes. A significant portion of acetylcholine's effect likely results from the modulation of GABAergic inhibitory interneurons, which have crucial roles in controlling excitatory inputs, synaptic integration, rhythmic coordination of principal neurons, and outputs in the hippocampus. Acetylcholine affects interneuron function in large part by altering their membrane potential via muscarinic and nicotinic receptor activation. This minireview describes recent data from mouse hippocampus that investigated changes in CA1 interneuron membrane potentials following acetylcholine release. The interneuron subtypes affected, the receptor subtypes activated, and the potential outcome on hippocampal CA1 network function is discussed.

Keywords: hippocampus, acetylcholine, muscarinic, nicotinic, inhibitory interneuron

\section{INTRODUCTION}

Acetylcholine is released throughout the mammalian central nervous system (CNS) where it impacts global brain function by affecting sleep-wake cycles, attention, and memory formation. One region of the brain heavily innervated by cholinergic afferents from the medial septum and diagonal band of Broca complex (MS/DBB) is the hippocampus (Dutar et al., 1995). Functionally, acetylcholine release in the hippocampus has been proposed to aid in the formation or retrieval of memories depending on the extracellular concentration of acetylcholine (Power et al., 2003; Hasselmo and Giocomo, 2006; Kenney and Gould, 2008; Deiana et al., 2011; Hasselmo and Sarter, 2011; Easton et al., 2012; Blake et al., 2014). The mechanism by which MS/DBB cholinergic terminals affect hippocampal network function is through the activation of both muscarinic and nicotinic receptors located on dendrites, cell bodies, and axon terminals of pyramidal neurons and inhibitory interneurons, as well as on astrocytes (Cobb and Davies, 2005; Teles-Grilo Ruivo and Mellor, 2013). Although acetylcholine affects multiple sites on several different cell types, a portion of its influence likely arises from its effects on interneuron function.

Inhibitory interneurons play a crucial role in information processing in the hippocampus. Interneurons are very diverse in anatomical structure and presumed function (Freund and Buzsaki, 1996; Klausberger and Somogyi, 2008). Depending on the interneuron subtype and where it innervates the pyramidal cell, an individual interneuron can completely block activity in a dendrite, change action potential firing phase at the soma, or completely prevent action potential firing at the pyramidal cell body (Miles et al., 1996; Larkum et al., 1999). At the network level, interneurons contribute to the generation of synchronous activity among populations of principal neurons at a variety of behaviorally relevant frequencies (Buzsaki, 2002; Buzsaki and Wang, 2012). Given the significant impact individual interneurons have on neuronal network function, it is probable that a considerable proportion of acetylcholine's influence on hippocampal activity arises through interneuron modulation. Although cholinergic receptors have been shown to affect inhibitory presynaptic terminals (Behrends and Ten Bruggencate, 1993; Tang et al., 2011) and interneuron excitability (McQuiston and Madison, 1999b; Griguoli et al., 2009; Cea-Del Rio et al., 2010, 2011), this minireview will limit its focus to recent studies that have investigated the effect of acetylcholine release on changes in interneuron membrane potential, specifically in hippocampal CA1.

\section{MS/DBB CHOLINERGIC NEURON ACTIVITY AND ACETYLCHOLINE RELEASE IN HIPPOCAMPAL CA1}

The impact that acetylcholine release has in hippocampal CA1 and the extent to which different interneuron subtypes are affected will depend on the specific location and density of cholinergic axon terminals as well as its inactivating enzyme, acetylcholinesterase. Notably, both cholinergic fibers and acetylcholinesterase have been shown to be differentially distributed across layers in hippocampal CA1. In mouse, cholinergic fibers were shown to be evenly distributed except for two bands of higher density in the stratum pyamidale (SP) and at the border between the stratum radiatum (SR) and stratum lacunosummoleculare (SLM) (Aznavour et al., 2002). In rat, similar higher density bands were observed in the SP and at the border of $\mathrm{SR}$ and SLM. However, compared to the stratum oriens (SO), 
lower densities were seen in the SR and even lower densities in SLM (SO > SR > SLM) (Aznavour et al., 2002). The distribution of acetylcholinesterase in hippocampal CA1 complements that of cholinergic input, with higher densities observed between SP and SO as well as another peak in SLM near the border with SR (Storm-Mathisen, 1970). Consistent with these anatomical data, measurements of increased acetylcholine release during theta rhythms have shown that acetylcholine concentrations were highest near the stratum pyramidale (Zhang et al., 2010). This differential distribution of cholinergic fibers and extracellular acetylcholine levels is particularly important when considering that not all cholinergic terminals in the hippocampus appear to transmit acetylcholine synaptically. In both the hippocampus and neocortex, $85-93 \%$ of cholinergic axon terminals were estimated to have no postsynaptic specialization and thus the majority of cholinergic terminals were proposed to transmit acetylcholine by volume or non-synaptic transmission (Umbriaco et al., 1994, 1995). However, other groups have estimated that the majority of cholinergic terminals (66-67\%) in the neocortex make classical synaptic connections (Smiley et al., 1997; Turrini et al., 2001). Regardless of this discrepancy, a significant portion of terminals appear to release acetylcholine into the extracellular space in a paracrine-like manner. This requires terminally released acetylcholine to diffuse significant distances past acetylcholinesterase to bind to receptors on postsynaptic elements. Thus, regions or layers with favorable densities of cholinergic terminals (higher) and/or acetylcholinesterase (lower) may result in larger extracellular concentrations of acetylcholine that may be more effective at transmitting acetylcholine through volume transmission. Furthermore, it is possible that there is a subset of terminals that are more active, have a higher probability of release, or may release more neurotransmitter. These terminals may be more effective at mediating volume transmission and influencing nearby inhibitory interneurons.

Acetylcholine release from cholinergic terminals will depend on the activity of the cholinergic neurons in the MS/DBB. However, the firing patterns of MS/DBB cholinergic neurons reported in the literature have shown some variability (Barrenechea et al., 1995; Brazhnik and Fox, 1997, 1999; Simon et al., 2006). A small number of anatomically identified MS/DBB cholinergic neurons recorded in awake restrained rodents have been reported to have low irregular firing rates $(<2 \mathrm{~Hz}$ ) (Simon et al., 2006). In contrast, anatomically unidentified neurons with action potential waveforms consistent with MS/DBB cholinergic neurons have been reported to fire at rates up to $30 \mathrm{~Hz}$ (Brazhnik and Fox, 1999). Thus, it remains unclear which rates best describe the firing patterns of cholinergic neurons in the MS/DBB or whether they fall along a wide continuum. Nevertheless, potential differences in the firing frequency or the duration of activity of cholinergic neurons could have variable effects on different interneuron subtypes through local differences in acetylcholine concentrations.

\section{EFFECTS OF MUSCARINIC RECEPTOR ACTIVATION ON HIPPOCAMPAL CA1 INHIBITORY INTERNEURONS}

Disruption of the MS/DBB cholinergic function by systemic blockade of muscarinic receptors or direct injection of muscarinic receptor antagonists into the hippocampus can impair memory and the encoding of spatial information (Blokland et al., 1992; Atri et al., 2004; Hasselmo, 2006). A potential role for inhibitory interneurons in muscarinic receptor modulation of hippocampal function was initially based on observations that the exogenous application of cholinergic agonists resulted in an increase in spontaneous inhibitory postsynaptic currents (sIPSCs) in CA1 pyramidal neurons (Pitler and Alger, 1992). These data indirectly suggested that a subset of inhibitory interneurons may be depolarized by muscarinic receptor activation and were subsequently confirmed by direct recordings (Parra et al., 1998; McQuiston and Madison, 1999a). However, not all interneurons responded to muscarinic receptor activation by depolarizing. Some interneurons were hyperpolarized or exhibited biphasic responses, and some failed to respond to the exogenous application of muscarinic agonist (Parra et al., 1998; McQuiston and Madison, 1999a). Moreover, each muscarinic response type could not be correlated with a morphological subtype of interneuron. These findings were further complicated by the observation that muscarinic receptors can inhibit the release of GABA from a subset of perisomatic inhibitory interneurons (Behrends and Ten Bruggencate, 1993; Fukudome et al., 2004; Szabo et al., 2010) and muscarinic receptor activation can increase interneuron excitability through the generation of after depolarizations (McQuiston and Madison, 1999b; Lawrence et al., 2006). Thus, the impact that acetylcholine release has on the interneuron population is complex and results in the recruitment of some interneurons while inhibiting others.

\section{ACTIVATION OF MUSCARINIC RECEPTORS IN HIPPOCAMPAL CA1 INTERNEURONS FOLLOWING ACETYLCHOLINE RELEASE}

Although cholinergic muscarinic synaptic responses were first measured in CA1 pyramidal neurons in 1983 (Cole and Nicoll, 1983), it was not until 2006 that muscarinic responses to electrically evoked acetylcholine release were measured in hippocampal CA1 inhibitory interneurons (Widmer et al., 2006). This study showed that terminally released acetylcholine had divergent effects on different interneuron subtypes. Interneurons could respond by depolarizing, hyperpolarizing, or with biphasic responses. Overall, the majority of responding interneurons produced depolarizations (64\%) whereas hyperpolarizations were infrequently observed (13\%) (Widmer et al., 2006). Moreover, like previous studies using exogenous application of muscarinic agonists (Parra et al., 1998; McQuiston and Madison, 1999a), the different electrically evoked muscarinic response types could not be correlated with specific interneuron anatomical subtypes (Widmer et al., 2006). These findings have been recently confirmed by optogenetic studies using evoked release in response to light-activation (Nagode et al., 2011; Bell et al., 2013). However, in one of these optogenetic studies, interneurons responding with biphasic (25\%), hyperpolarizing (35\%), and depolarizing (40\%) muscarinic responses were more equally distributed among the different response types (Bell et al., 2013). Importantly, optogenetically released acetylcholine predominantly produced muscarinic responses $(80 \%)$ vs. nicotinic responses $(17 \%)$. The remaining $3 \%$ of responding interneurons had both muscarinic 
and nicotinic responses. Furthermore, the muscarinic hyperpolarizations were mediated by the activation of $\mathrm{M}_{4}$ receptors whereas the depolarizations were likely produced by $\mathrm{M}_{3}$ receptor activation (Bell et al., 2013). Similar to the electrical stimulation studies, muscarinic response type could not be correlated with anatomical interneuron subtypes. Importantly, both studies showed that perisomatically projecting interneurons (likely parvalbumin-expressing basket cells) could respond to acetylcholine release with any one of the three muscarinic response types (Widmer et al., 2006; Bell et al., 2013). In different optogenetic studies, CA1 interneuron membrane potential was indirectly assessed by measuring sIPSC frequency in CA1 pyramidal neurons (Nagode et al., 2011, 2014). Optogenetically released acetylcholine resulted in an increase in large amplitude sIPSCs with frequencies that fell within the theta bandwidth $(4-12 \mathrm{~Hz})$ (Nagode et al., 2011). Importantly, this increase in sIPSCs could be inhibited by endocannabinoids suggesting that they resulted from the activation of cholecystokinin positive interneurons
(Nagode et al., 2011). Furthermore, the sIPSCs were not affected by optogenetic suppression of parvalbumin positive cells, suggesting they did not arise from the activation of parvalbumin basket cells, axo-axonic, bistratified or oriens-lacunosum-moleculare interneurons (Nagode et al., 2014). These findings are consistent with synaptic stimulation studies, which recorded from an interneuron with cholecystokinin basket cell morphology that produced a biphasic response to acetylcholine release (Widmer et al., 2006). Therefore, based on effects on the membrane potential alone, endogenously activated muscarinic receptors on hippocampal CA1 interneurons will have complex effects on network function (see Table 1).

Although different muscarinic response types were almost uniformly observed in CA1 interneurons, not all response types were as easily evoked by optogenetic stimulation (Bell et al., 2013). Consistent with some in vivo recordings (Brazhnik and Fox, 1999), acetylcholine released from MS/DBB cholinergic terminals by blue light flashes delivered at $20 \mathrm{~Hz}$ was capable of producing

Table 1 | Cholinergic responses vary in similar and different anatomical interneuron subtypes.

\begin{tabular}{|c|c|c|c|c|c|c|}
\hline $\begin{array}{l}\text { Interneuron } \\
\text { axonal } \\
\text { arborization }\end{array}$ & Muscarinic depol. & $\begin{array}{l}\text { Muscarinic } \\
\text { hyperpol. }\end{array}$ & Muscarinic biphasic & Nicotinic $\alpha 7$ & Nicotinic $\alpha 4 \beta 2$ & Nicotinic $\alpha 2$ \\
\hline Perisomatic SP & $\begin{array}{l}\text { Synaptic: } \\
\text { Widmer et al., 2006; } \\
\text { Nagode et al., 2011; } \\
\text { 2014; Bell et al., } 2013\end{array}$ & $\begin{array}{l}\text { Synaptic: } \\
\text { Widmer et al., 2006; } \\
\text { Bell et al., } 2013\end{array}$ & $\begin{array}{l}\text { Synaptic: } \\
\text { Widmer et al., 2006; } \\
\text { Bell et al., } 2013\end{array}$ & $\begin{array}{l}\text { Synaptic: } \\
\text { Not identified }\end{array}$ & $\begin{array}{l}\text { Synaptic: } \\
\text { Not identified }\end{array}$ & $\begin{array}{l}\text { Synaptic: } \\
\text { Not observed }\end{array}$ \\
\hline \multirow[t]{2}{*}{$\begin{array}{l}\text { Proximal } \\
\text { dendritic SR or } \\
\text { SO }\end{array}$} & $\begin{array}{l}\text { Agonist: } \\
\text { Parra et al., 1998; } \\
\text { McQuiston and } \\
\text { Madison, 1999a }\end{array}$ & $\begin{array}{l}\text { Agonist: } \\
\text { McQuiston and } \\
\text { Madison, 1999a }\end{array}$ & $\begin{array}{l}\text { Agonist: } \\
\text { McQuiston and } \\
\text { Madison, 1999a }\end{array}$ & $\begin{array}{l}\text { Agonist: } \\
\text { McQuiston and } \\
\text { Madison, 1999c; } \\
\text { Buhler and } \\
\text { Dunwiddie, } 2001\end{array}$ & $\begin{array}{l}\text { Agonist: } \\
\text { Not identified }\end{array}$ & $\begin{array}{l}\text { Agonist: } \\
\text { Not identified }\end{array}$ \\
\hline & $\begin{array}{l}\text { Synaptic: } \\
\text { Widmer et al., 2006; } \\
\text { Bell et al., } 2013\end{array}$ & $\begin{array}{l}\text { Synaptic: } \\
\text { Widmer et al., 2006; } \\
\text { Bell et al., } 2013\end{array}$ & $\begin{array}{l}\text { Synaptic: } \\
\text { Widmer et al., 2006; } \\
\text { Bell et al., } 2013\end{array}$ & $\begin{array}{l}\text { Synaptic: } \\
\text { Not identified }\end{array}$ & $\begin{array}{l}\text { Synaptic: } \\
\text { Bell et al., } 2011\end{array}$ & $\begin{array}{l}\text { Synaptic: } \\
\text { Not observed }\end{array}$ \\
\hline $\begin{array}{l}\text { Distal dendritic } \\
\text { SLM }\end{array}$ & $\begin{array}{l}\text { Agonist: } \\
\text { Parra et al., 1998; } \\
\text { McQuiston and } \\
\text { Madison, 1999a }\end{array}$ & $\begin{array}{l}\text { Agonist: } \\
\text { Parra et al., 1998; } \\
\text { McQuiston and } \\
\text { Madison, 1999a }\end{array}$ & $\begin{array}{l}\text { Agonist: } \\
\text { McQuiston and } \\
\text { Madison, 1999a }\end{array}$ & $\begin{array}{l}\text { Agonist: } \\
\text { McQuiston and } \\
\text { Madison, 1999c; } \\
\text { Buhler and } \\
\text { Dunwiddie, 2001; } \\
\text { Griguoli et al., } 2009\end{array}$ & $\begin{array}{l}\text { Agonist: } \\
\text { Griguoli et al., } 2009\end{array}$ & $\begin{array}{l}\text { Agonist: } \\
\text { McQuiston and } \\
\text { Madison, 1999c; } \\
\text { Griguoli et al., } 2009\end{array}$ \\
\hline
\end{tabular}

Cholinergic responsive interneurons are categorized based on the anatomical location of their axons (left column). References are reported for cholinergic response types observed in each class of interneuron. Agonist refers to responses elicited by exogenous agonist application. Stimulation refers to endogenous acetylcholine responses elicited electrically or optogenetically. Not identified-indicates that such a response type has not been observed in that class of interneuron. Not observed-indicates that no such response type has been observed in any interneuron class. 
each response type in hippocampal CA1 interneurons (Bell et al., 2013). However, the number of flashes affected the probability of observing a particular response type. In hyperpolarizing interneurons, 10 flashes were sufficient (91\% of hyperpolarizing interneurons) to observe a response. In contrast, 10 flashes were not sufficient to produce a response in the majority of depolarizing interneurons $(58 \%)$. Similarly, the depolarizing phase could not be observed in the majority of biphasic interneurons (55\%) when only 10 stimuli were delivered. Therefore, muscarinic hyperpolarizations may require less presynaptic MS/DBB cholinergic activity compared to depolarizing responses in hippocampal CA1 interneurons. It may be that suppression of interneuron excitability will be the predominant effect in response to low levels of MS/DBB cholinergic activity.

\section{EFFECTS OF NICOTINIC RECEPTOR ACTIVATION ON HIPPOCAMPAL CA1 INTERNEURONS}

Activation of nicotinic receptors in the hippocampus has a significant impact on physiological and pathophysiological memory formation (Levin, 2002; Levin et al., 2002, 2009; Buccafusco et al., 2005; Davis and Gould, 2006, 2009; Nott and Levin, 2006; Davis et al., 2007). Of the 11 different nicotinic receptor subunits found in the mammalian CNS, 9 have been reported to be expressed in hippocampal CA1 neurons (Sudweeks and Yakel, 2000). Using exogenous application of nicotinic agonists, functional nicotinic receptors that contain $\alpha 7$ (Alkondon et al., 1997; Jones and Yakel, 1997; Frazier et al., 1998b; McQuiston and Madison, 1999c), $\alpha 4 \beta 2$ (McQuiston and Madison, 1999c; Sudweeks and Yakel, 2000), or $\alpha 2$ subunits (McQuiston and Madison, 1999c; Sudweeks and Yakel, 2000; Jia et al., 2009) have been observed in hippocampal CA1 interneurons. Although hippocampal interneurons appeared to express a diverse collection nicotinic receptor subtypes, $\alpha 7$ containing receptors were more frequently observed and produced larger responses (McQuiston and Madison, 1999c; Sudweeks and Yakel, 2000). Indeed, $\alpha 7$ nicotinic receptors in the hippocampus have been associated with memory formation (Levin, 2002; Levin et al., 2002; Nott and Levin, 2006) and their dysfunction may play a role in some forms of schizophrenia (Freedman et al., 1994; Leonard et al., 1996; Adler et al., 1998). However, despite their lower expression levels, the $\alpha 4 \beta 2$ containing nicotinic receptors have been reported to play a significant role in memory formation (Davis and Gould, 2006; Davis et al., 2007) and in hippocampal-dependent nicotine addiction (Perry et al., 1999; Davis and Gould, 2009). $\alpha 4 \beta 2$ containing receptors have also been correlated with cognitive deficits associated with aging and Alzheimer's disease (Kellar et al., 1987; Wu et al., 2004; Gahring et al., 2005). To fully understand the role that different nicotinic subunits play in the hippocampus, the effect of endogenously released acetylcholine on individual hippocampal cells and the hippocampal network has begun to be investigated.

\section{ACTIVATION OF NICOTINIC RECEPTORS IN HIPPOCAMPAL CA1 INTERNEURONS FOLLOWING ACETYLCHOLINE RELEASE}

Acetylcholine release from MS/DBB cholinergic terminals in hippocampal CA1 has been demonstrated to activate nicotinic receptors on interneurons (Alkondon et al., 1998; Frazier et al., 1998a; Stone, 2007). Nicotinic excitatory postsynaptic currents (EPSCs) were first observed using electrical stimulation and whole cell patch clamping in acute rat brain slices. These nicotinic EPSCs had fast kinetics and were blocked by $\alpha 7$ nicotinic receptor antagonists (Alkondon et al., 1998; Frazier et al., 1998a), consistent with studies that applied nicotinic receptor agonists directly onto interneuron cell bodies (Alkondon et al., 1997; Jones and Yakel, 1997; Frazier et al., 1998b; McQuiston and Madison, 1999c). However, more recent optogenetic studies in mouse brain slices were not able to reproduce these earlier observations (Bell et al., 2011). Instead, optogenetically released acetylcholine primarily activated nicotinic receptors that contained $\alpha 4 \beta 2$ subunits. Furthermore, the $\alpha 4 \beta 2$ responses were mostly subthreshold and had very slow kinetics. These data were suggestive of acetylcholine diffusing a significant distance before binding to the $\alpha 4 \beta 2$ containing nicotinic receptors (McQuiston and Madison, 1999c; Bennett et al., 2012), consistent with volume or non-synaptic transmission (Vizi et al., 2010). Although these small nicotinic responses could temporally summate, their ability to excite interneurons was limited through muscarinic presynaptic inhibition. Because the nicotinic responses were mostly subthreshold, nicotinic transmission onto CA1 interneurons may be primarily modulatory in nature. The optogenetic studies also examined the nicotinic responses using voltage-sensitive dye (VSD) imaging. The nicotinic VSD signals were completely blocked by the $\alpha 4 \beta 2$ receptor antagonist $\mathrm{DH} \beta \mathrm{E}$ and were found to be significantly larger in the distal dendritic region of CA1 pyramidal neurons, which overlaps with inputs from the entorhinal cortex and nucleus reuniens of the thalamus (Bell et al., 2011). Importantly, because the VSD stains all elements of the tissue, the VSD data suggest that $\alpha 4 \beta 2$ containing nicotinic receptors are the most prevalent receptor that mediates depolarizing nicotinic responses in mouse hippocampal CA1. Notably, nicotinic responses could be produced by a single flash of light (Bell et al., 2011) suggesting that acetylcholine release from MS/DBB cholinergic terminals may help recruit interneurons via nicotinic receptor activation before they are affected by muscarinic receptor activation.

\section{EFFECTS OF ACETYLCHOLINE RELEASE ON HIPPOCAMPAL CA1 NETWORK FUNCTION FROM THE PERSPECTIVE OF THE INTERNEURON MEMBRANE POTENTIAL}

Because CA1 inhibitory interneuron membrane potentials can be differentially modulated by both muscarinic and nicotinic receptor activation following acetylcholine release, the consequential effect on network function is undoubtedly complex. Muscarinic receptor activation can result in varying and opposing effects, even within the same interneuron (see Table 1). Unfortunately, our understanding of how each subtype of interneuron can be affected by muscarinic or nicotinic receptor activation remains incomplete. Nevertheless, the number of stimuli required to produce each type of response varied in a consistent manner. Nicotinic responses were most easily evoked requiring the fewest number of stimuli (Bell et al., 2011) whereas depolarizing muscarinic responses were the most difficult to produce requiring the largest number stimuli (Bell et al., 2013). Therefore, it can be hypothesized that low levels of MS/DBB cholinergic 


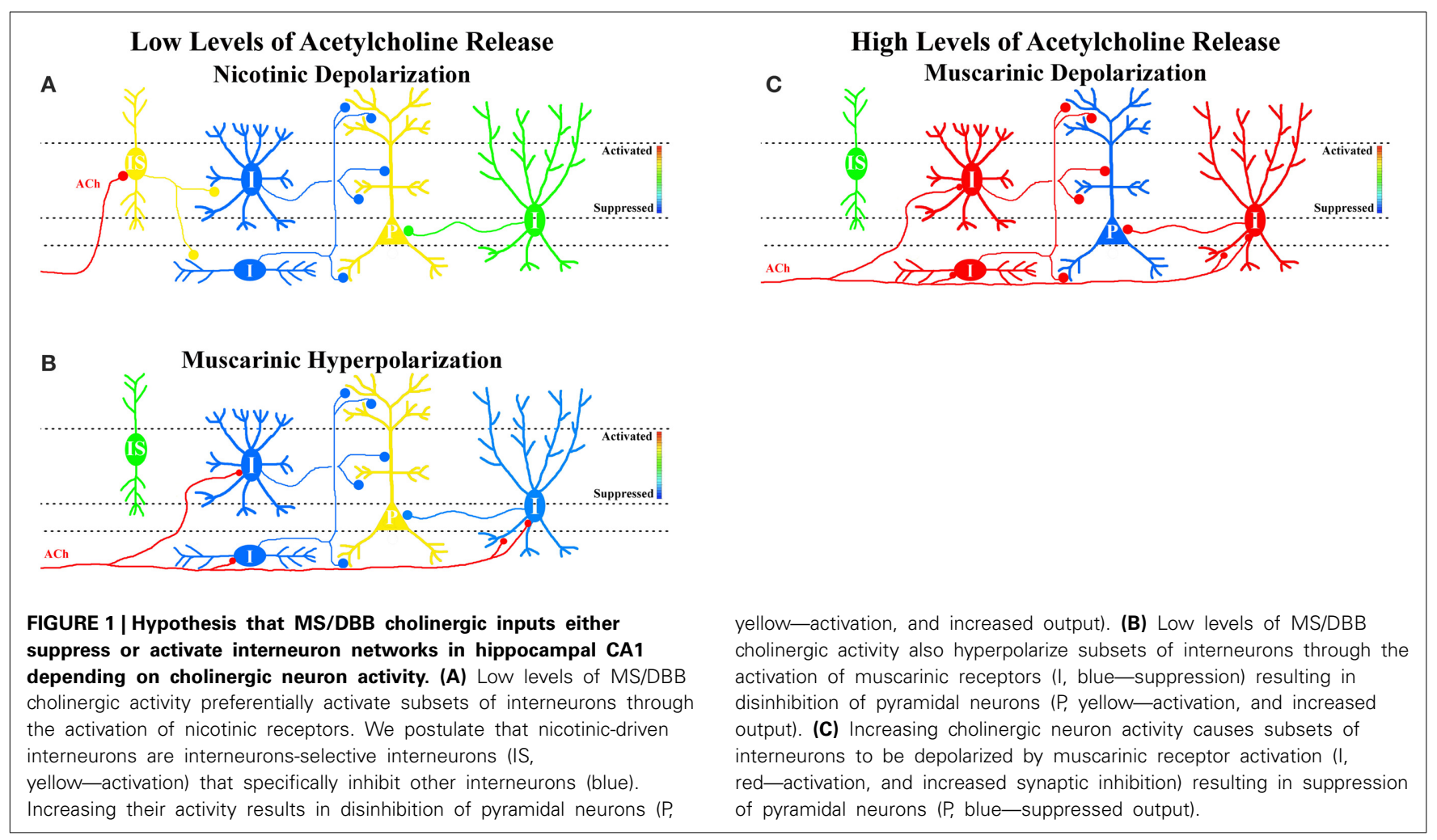

neuron activity and lower concentrations of extracellular acetylcholine favor the activation nicotinic receptors or a muscarinic hyperpolarization in specific subsets of CA1 interneurons.

Because muscarinic hyperpolarization of CA1 interneurons requires less presynaptic cholinergic activity, disinhibition (indirect activation) of hippocampal CA1 pyramidal cells may be favored during low levels of MS/DBB cholinergic activity (Figure 1B). Furthermore, postulating that nicotinic responses preferentially affect interneurons that selectively inhibit other interneurons (interneuron-selective or IS), nicotinic receptor activation may also result in disinhibition of CA1 pyramidal neurons (Figure 1A). Together, low levels of MS/DBB cholinergic activity would favor a net disinhibition of hippocampal CA1 permitting higher probability of output from CA1 pyramidal neurons. Increased output from CA1 may result in the facilitation of recall and memory consolidation in other areas of the CNS as is thought to occur during slow wave sleep (Gais and Born, 2004; Hasselmo and McGaughy, 2004). In contrast, higher levels of MS/DBB cholinergic neuron activity coupled to higher extracellular concentrations of acetylcholine will subsequently recruit different subsets of interneurons that respond via muscarinic depolarizations. Some of these depolarizing interneurons may impose rhythmic inhibition of CA1 pyramidal neurons at theta frequencies (Nagode et al., 2011, 2014), a network rhythm observed during higher levels of acetylcholine release (Zhang et al., 2010). This would result in inhibition of hippocampal CA1 pyramidal neuron output (partly rhythmic) while facilitating synaptic integration within hippocampal CA1 pyramidal cell dendrites through cholinergic effects on glutamatergic receptors and dendritic function (Figure 1C) (Tsubokawa and Ross,
1997; Tsubokawa, 2000; Fernandez De Sevilla and Buno, 2010; Giessel and Sabatini, 2010). Indeed, such a dynamic role for acetylcholine concentrations in learning and memory formation has been previously proposed (Hasselmo, 2006; Hasselmo and Giocomo, 2006; Giocomo and Hasselmo, 2007; Hasselmo and Sarter, 2011). In this scheme, lower acetylcholine concentrations permit intrahippocampal (Schaffer collaterals) synaptic interactions to dominate thus increasing hippocampal CAl output and memory retrieval, whereas higher acetylcholine concentrations favor processing of inputs from outside the hippocampus permitting the transient formation of memories in hippocampal CA1. Therefore, the combined effect of acetylcholine release on glutamatergic inputs and interneuron function may play important roles in tuning the hippocampal CA1 network for recall or to form new memories.

\section{ACKNOWLEDGMENT}

This work was supported by grants from the NIMH/NIH 5R01MH094626 and 1R21MH103695.

\section{REFERENCES}

Adler, L. E., Olincy, A., Waldo, M., Harris, J. G., Griffith, J., Stevens, K., et al. (1998). Schizophrenia, sensory gating, and nicotinic receptors. Schizophr. Bull. 24, 189-202. doi: 10.1093/oxfordjournals.schbul.a033320

Alkondon, M., Pereira, E. F., and Albuquerque, E. X. (1998). alpha-bungarotoxinand methyllycaconitine-sensitive nicotinic receptors mediate fast synaptic transmission in interneurons of rat hippocampal slices. Brain Res. 810, 257-263. doi: 10.1016/S0006-8993(98)00880-4

Alkondon, M., Pereira, E. F., Barbosa, C. T., and Albuquerque, E. X. (1997). Neuronal nicotinic acetylcholine receptor activation modulates gammaaminobutyric acid release from CA1 neurons of rat hippocampal slices. J. Pharmacol. Exp. Ther. 283, 1396-1411. 
Atri, A., Sherman, S., Norman, K. A., Kirchhoff, B. A., Nicolas, M. M., Greicius, M. D., et al. (2004). Blockade of central cholinergic receptors impairs new learning and increases proactive interference in a word paired-associate memory task. Behav. Neurosci. 118, 223-236. doi: 10.1037/0735-7044.118.1.223

Aznavour, N., Mechawar, N., and Descarries, L. (2002). Comparative analysis of cholinergic innervation in the dorsal hippocampus of adult mouse and rat: a quantitative immunocytochemical study. Hippocampus 12, 206-217. doi: 10.1002/hipo.1108

Barrenechea, C., Pedemonte, M., Nunez, A., and Garcia-Austt, E. (1995). In vivo intracellular recordings of medial septal and diagonal band of Broca neurons: relationships with theta rhythm. Exp. Brain Res. 103, 31-40. doi: 10.1007/BF00241962

Behrends, J. C., and Ten Bruggencate, G. (1993). Cholinergic modulation of synaptic inhibition in the guinea pig hippocampus in vitro: excitation of GABAergic interneurons and inhibition of GABA-release. J. Neurophysiol. 69, 626-629.

Bell, K. A., Shim, H., Chen, C. K., and McQuiston, A. R. (2011). Nicotinic excitatory postsynaptic potentials in hippocampal CA1 interneurons are predominantly mediated by nicotinic receptors that contain alpha4 and beta2 subunits. Neuropharmacology 61, 1379-1388. doi: 10.1016/j.neuropharm.2011.08.024

Bell, L. A., Bell, K. A., and McQuiston, A. R. (2013). Synaptic muscarinic response types in hippocampal CA1 interneurons depend on different levels of presynaptic activity and different muscarinic receptor subtypes. Neuropharmacology 73 , 160-173. doi: 10.1016/j.neuropharm.2013.05.026

Bennett, C., Arroyo, S., Berns, D., and Hestrin, S. (2012). Mechanisms generating dual-component nicotinic EPSCs in cortical interneurons. J. Neurosci. 32, 17287-17296. doi: 10.1523/JNEUROSCI.3565-12.2012

Blake, M. G., Krawczyk, M. C., Baratti, C. M., and Boccia, M. M. (2014). Neuropharmacology of memory consolidation and reconsolidation: insights on central cholinergic mechanisms. J. Physiol. Paris. doi: 10.1016/j.jphysparis.2014.04.005. [Epub ahead of print]

Blokland, A., Honig, W., and Raaijmakers, W. G. (1992). Effects of intrahippocampal scopolamine injections in a repeated spatial acquisition task in the rat. Psychopharmacology (Berl). 109, 373-376. doi: 10.1007/BF02245886

Brazhnik, E. S., and Fox, S. E. (1997). Intracellular recordings from medial septal neurons during hippocampal theta rhythm. Exp. Brain Res. 114, 442-453. doi: 10.1007/PL00005653

Brazhnik, E. S., and Fox, S. E. (1999). Action potentials and relations to the theta rhythm of medial septal neurons in vivo. Exp. Brain Res. 127, 244-258. doi $10.1007 / \mathrm{s} 002210050794$

Buccafusco, J. J., Letchworth, S. R., Bencherif, M., and Lippiello, P. M. (2005). Long-lasting cognitive improvement with nicotinic receptor agonists: mechanisms of pharmacokinetic-pharmacodynamic discordance. Trends Pharmacol. Sci. 26, 352-360. doi: 10.1016/j.tips.2005.05.007

Buhler, A. V., and Dunwiddie, T. V. (2001). Regulation of the activity of hippocampal stratum oriens interneurons by alpha7 nicotinic acetylcholine receptors. Neuroscience 106, 55-67. doi: 10.1016/S0306-4522(01)00257-3

Buzsaki, G. (2002). Theta oscillations in the hippocampus. Neuron 33, 325-340. doi: 10.1016/S0896-6273(02)00586-X

Buzsaki, G., and Wang, X. J. (2012). Mechanisms of gamma oscillations. Annu. Rev. Neurosci. 35, 203-225. doi: 10.1146/annurev-neuro-062111-150444

Cea-Del Rio, C. A., Lawrence, J. J., Erdelyi, F., Szabo, G., and McBain, C. J. (2011). Cholinergic modulation amplifies the intrinsic oscillatory properties of CA1 hippocampal cholecystokinin-positive interneurons. J. Physiol. 589, 609-627. doi: 10.1113/jphysiol.2010.199422

Cea-Del Rio, C. A., Lawrence, J. J., Tricoire, L., Erdelyi, F., Szabo, G., and McBain, C. J. (2010). M3 muscarinic acetylcholine receptor expression confers differential cholinergic modulation to neurochemically distinct hippocampal basket cell subtypes. J. Neurosci. 30, 6011-6024. doi: 10.1523/JNEUROSCI.5040-09.2010

Cobb, S. R., and Davies, C. H. (2005). Cholinergic modulation of hippocampal cells and circuits. J. Physiol. 562, 81-88. doi: 10.1113/jphysiol.2004.076539

Cole, A. E., and Nicoll, R. A. (1983). Acetylcholine mediates a slow synaptic potential in hippocampal pyramidal cells. Science 221, 1299-1301. doi: $10.1126 /$ science.6612345

Davis, J. A., and Gould, T. J. (2006). The effects of DHBE and MLA on nicotineinduced enhancement of contextual fear conditioning in C57BL/6 mice. Psychopharmacology (Berl). 184, 345-352. doi: 10.1007/s00213-005-0047-y

Davis, J. A., and Gould, T. J. (2009). Hippocampal nAChRs mediate nicotine withdrawal-related learning deficits. Eur. Neuropsychopharmacol. 19, 551-561. doi: 10.1016/j.euroneuro.2009.02.003
Davis, J. A., Kenney, J. W., and Gould, T. J. (2007). Hippocampal alpha4beta2 nicotinic acetylcholine receptor involvement in the enhancing effect of acute nicotine on contextual fear conditioning. J. Neurosci. 27, 10870-10877. doi: 10.1523/JNEUROSCI.3242-07.2007

Deiana, S., Platt, B., and Riedel, G. (2011). The cholinergic system and spatial learning. Behav. Brain Res. 221, 389-411. doi: 10.1016/j.bbr.2010.11.036

Dutar, P., Bassant, M. H., Senut, M. C., and Lamour, Y. (1995). The septohippocampal pathway: structure and function of a central cholinergic system. Physiol. Rev. 75, 393-427.

Easton, A., Douchamps, V., Eacott, M., and Lever, C. (2012). A specific role for septohippocampal acetylcholine in memory? Neuropsychologia 50, 3156-3168. doi: 10.1016/j.neuropsychologia.2012.07.022

Fernandez De Sevilla, D., and Buno, W. (2010). The muscarinic long-term enhancement of NMDA and AMPA receptor-mediated transmission at Schaffer collateral synapses develop through different intracellular mechanisms. J. Neurosci. 30, 11032-11042. doi: 10.1523/JNEUROSCI.1848-10.2010

Frazier, C. J., Buhler, A. V., Weiner, J. L., and Dunwiddie, T. V. (1998a). Synaptic potentials mediated via alpha-bungarotoxin-sensitive nicotinic acetylcholine receptors in rat hippocampal interneurons. J. Neurosci. 18, 8228-8235.

Frazier, C. J., Rollins, Y. D., Breese, C. R., Leonard, S., Freedman, R., and Dunwiddie, T. V. (1998b). Acetylcholine activates an alpha-bungarotoxinsensitive nicotinic current in rat hippocampal interneurons, but not pyramidal cells. J. Neurosci. 18, 1187-1195.

Freedman, R., Adler, L. E., Bickford, P., Byerley, W., Coon, H., Cullum, C. M., et al. (1994). Schizophrenia and nicotinic receptors. Harv. Rev. Psychiatry 2, 179-192. doi: 10.3109/10673229409017136

Freund, T. F., and Buzsaki, G. (1996). Interneurons of the hippocampus. Hippocampus 6, 347-470.

Fukudome, Y., Ohno-Shosaku, T., Matsui, M., Omori, Y., Fukaya, M., Tsubokawa, H., et al. (2004). Two distinct classes of muscarinic action on hippocampal inhibitory synapses: M2-mediated direct suppression and M1/M3-mediated indirect suppression through endocannabinoid signalling. Eur. J. Neurosci. 19, 2682-2692. doi: 10.1111/j.0953-816X.2004.03384.x

Gahring, L. C., Persiyanov, K., and Rogers, S. W. (2005). Mouse strain-specific changes in nicotinic receptor expression with age. Neurobiol. Aging 26, 973-980. doi: 10.1016/j.neurobiolaging.2004.07.005

Gais, S., and Born, J. (2004). Low acetylcholine during slow-wave sleep is critical for declarative memory consolidation. Proc. Natl. Acad. Sci. U.S.A. 101, 2140-2144. doi: 10.1073/pnas.0305404101

Giessel, A. J., and Sabatini, B. L. (2010). M1 muscarinic receptors boost synaptic potentials and calcium influx in dendritic spines by inhibiting postsynaptic SK channels. Neuron 68, 936-947. doi: 10.1016/j.neuron.2010.09.004

Giocomo, L. M., and Hasselmo, M. E. (2007). Neuromodulation by glutamate and acetylcholine can change circuit dynamics by regulating the relative influence of afferent input and excitatory feedback. Mol. Neurobiol. 36, 184-200. doi: $10.1007 / \mathrm{s} 12035-007-0032-\mathrm{z}$

Griguoli, M., Scuri, R., Ragozzino, D., and Cherubini, E. (2009). Activation of nicotinic acetylcholine receptors enhances a slow calcium-dependent potassium conductance and reduces the firing of stratum oriens interneurons. Eur. J. Neurosci. 30, 1011-1022. doi: 10.1111/j.1460-9568.2009. 06914.x

Hasselmo, M. E. (2006). The role of acetylcholine in learning and memory. Curr. Opin. Neurobiol. 16, 710-715. doi: 10.1016/j.conb.2006.09.002

Hasselmo, M. E., and Giocomo, L. M. (2006). Cholinergic modulation of cortical function. J. Mol. Neurosci. 30, 133-135. doi: 10.1385/JMN:30:1:133

Hasselmo, M. E., and McGaughy, J. (2004). High acetylcholine levels set circuit dynamics for attention and encoding and low acetylcholine levels set dynamics for consolidation. Prog. Brain Res. 145, 207-231. doi: 10.1016/S00796123(03)45015-2

Hasselmo, M. E., and Sarter, M. (2011). Modes and models of forebrain cholinergic neuromodulation of cognition. Neuropsychopharmacology 36, 52-73. doi: 10.1038/npp.2010.104

Jia, Y., Yamazaki, Y., Nakauchi, S., and Sumikawa, K. (2009). Alpha2 nicotine receptors function as a molecular switch to continuously excite a subset of interneurons in rat hippocampal circuits. Eur. J. Neurosci. 29, 1588-1603. doi: 10.1111/j.1460-9568.2009.06706.x

Jones, S., and Yakel, J. L. (1997). Functional nicotinic ACh receptors on interneurones in the rat hippocampus. J. Physiol. 504(Pt 3), 603-610. doi: 10.1111/j.1469-7793.1997.603bd.x 
Kellar, K. J., Whitehouse, P. J., Martino-Barrows, A. M., Marcus, K., and Price, D. L. (1987). Muscarinic and nicotinic cholinergic binding sites in Alzheimer's disease cerebral cortex. Brain Res. 436, 62-68. doi: 10.1016/0006-8993(87) 91556-3

Kenney, J. W., and Gould, T. J. (2008). Modulation of hippocampus-dependent learning and synaptic plasticity by nicotine. Mol. Neurobiol. 38, 101-121. doi: 10.1007/s12035-008-8037-9

Klausberger, T., and Somogyi, P. (2008). Neuronal diversity and temporal dynamics: the unity of hippocampal circuit operations. Science 321, 53-57. doi: 10.1126/science.1149381

Larkum, M. E., Zhu, J. J., and Sakmann, B. (1999). A new cellular mechanism for coupling inputs arriving at different cortical layers. Nature 398, 338-341. doi: $10.1038 / 18686$

Lawrence, J. J., Statland, J. M., Grinspan, Z. M., and McBain, C. J. (2006) Cell type-specific dependence of muscarinic signalling in mouse hippocampal stratum oriens interneurones. J. Physiol. 570, 595-610. doi: 10.1113/jphysiol.2005.100875

Leonard, S., Adams, C., Breese, C. R., Adler, L. E., Bickford, P., Byerley, W., et al. (1996). Nicotinic receptor function in schizophrenia. Schizophr. Bull. 22, 431-445. doi: 10.1093/schbul/22.3.431

Levin, E. D. (2002). Nicotinic receptor subtypes and cognitive function. J. Neurobiol. 53, 633-640. doi: 10.1002/neu.10151

Levin, E. D., Bradley, A., Addy, N., and Sigurani, N. (2002). Hippocampal alpha 7 and alpha 4 beta 2 nicotinic receptors and working memory. Neuroscience 109 757-765. doi: 10.1016/S0306-4522(01)00538-3

Levin, E. D., Petro, A., Rezvani, A. H., Pollard, N., Christopher, N. C., Strauss, M. et al. (2009). Nicotinic alpha7- or beta2-containing receptor knockout: effects on radial-arm maze learning and long-term nicotine consumption in mice. Behav. Brain Res. 196, 207-213. doi: 10.1016/j.bbr.2008.08.048

McQuiston, A. R., and Madison, D. V. (1999a). Muscarinic receptor activity has multiple effects on the resting membrane potentials of CA1 hippocampal interneurons. J. Neurosci. 19, 5693-5702.

McQuiston, A. R., and Madison, D. V. (1999b). Muscarinic receptor activity induces an afterdepolarization in a subpopulation of hippocampal CA1 interneurons. J. Neurosci. 19, 5703-5710.

McQuiston, A. R., and Madison, D. V. (1999c). Nicotinic receptor activation excites distinct subtypes of interneurons in the rat hippocampus. J. Neurosci. 19 2887-2896.

Miles, R., Toth, K., Gulyas, A. I., Hajos, N., and Freund, T. F. (1996). Differences between somatic and dendritic inhibition in the hippocampus. Neuron 16 815-823. doi: 10.1016/S0896-6273(00)80101-4

Nagode, D. A., Tang, A. H., Karson, M. A., Klugmann, M., and Alger, B. E. (2011). Optogenetic release of ACh induces rhythmic bursts of perisomatic IPSCs in hippocampus. PLoS ONE 6:e27691. doi: 10.1371/journal.pone.0027691

Nagode, D. A., Tang, A. H., Yang, K., and Alger, B. E. (2014). Optogenetic identification of an intrinsic cholinergically driven inhibitory oscillator sensitive to cannabinoids and opioids in hippocampal CA1. J. Physiol. 592, 103-123. doi: 10.1113/jphysiol.2013.257428

Nott, A., and Levin, E. D. (2006). Dorsal hippocampal alpha7 and alpha4beta2 nicotinic receptors and memory. Brain Res. 1081, 72-78. doi: 10.1016/j.brainres.2006.01.052

Parra, P., Gulyas, A. I., and Miles, R. (1998). How many subtypes of inhibitory cells in the hippocampus? Neuron 20, 983-993. doi: 10.1016/S0896-6273(00) 80479-1

Perry, D. C., Davila-Garcia, M. I., Stockmeier, C. A., and Kellar, K. J. (1999). Increased nicotinic receptors in brains from smokers: membrane binding and autoradiography studies. J. Pharmacol. Exp. Ther. 289, 1545-1552.

Pitler, T. A., and Alger, B. E. (1992). Cholinergic excitation of GABAergic interneurons in the rat hippocampal slice. J. Physiol. 450, 127-142.

Power, A. E., Vazdarjanova, A., and McGaugh, J. L. (2003). Muscarinic cholinergic influences in memory consolidation. Neurobiol. Learn. Mem. 80, 178-193. doi: 10.1016/S1074-7427(03)00086-8

Simon, A. P., Poindessous-Jazat, F., Dutar, P., Epelbaum, J., and Bassant, M. H. (2006). Firing properties of anatomically identified neurons in the medial septum of anesthetized and unanesthetized restrained rats. J. Neurosci. 26 9038-9046. doi: 10.1523/JNEUROSCI.1401-06.2006

Smiley, J. F., Morrell, F., and Mesulam, M. M. (1997). Cholinergic synapses in human cerebral cortex: an ultrastructural study in serial sections. Exp. Neurol. 144, 361-368. doi: 10.1006/exnr.1997.6413
Stone, T. W. (2007). Kynurenic acid blocks nicotinic synaptic transmission to hippocampal interneurons in young rats. Eur. J. Neurosci. 25, 2656-2665. doi: 10.1111/j.1460-9568.2007.05540.x

Storm-Mathisen, J. (1970). Quantitative histochemistry of acetylcholinesterase in rat hippocampal region correlated to histochemical staining. J. Neurochem. 17, 739-750. doi: 10.1111/j.1471-4159.1970.tb03344.x

Sudweeks, S. N., and Yakel, J. L. (2000). Functional and molecular characterization of neuronal nicotinic ACh receptors in rat CA1 hippocampal neurons. J. Physiol. 527(Pt 3), 515-528. doi: 10.1111/j.1469-7793.2000.00515.x

Szabo, G. G., Holderith, N., Gulyas, A. I., Freund, T. F., and Hajos, N. (2010). Distinct synaptic properties of perisomatic inhibitory cell types and their different modulation by cholinergic receptor activation in the CA3 region of the mouse hippocampus. Eur. J. Neurosci. 31, 2234-2246. doi: 10.1111/j.14609568.2010.07292.x

Tang, A. H., Karson, M. A., Nagode, D. A., McIntosh, J. M., Uebele, V. N., Renger, J. J., et al. (2011). Nerve terminal nicotinic acetylcholine receptors initiate quantal GABA release from perisomatic interneurons by activating axonal T-type (Cav3) $\mathrm{Ca}(2)(+)$ channels and $\mathrm{Ca}(2)(+)$ release from stores. J. Neurosci. 31, 13546-13561. doi: 10.1523/JNEUROSCI.2781-11.2011

Teles-Grilo Ruivo, L. M., and Mellor, J. R. (2013). Cholinergic modulation of hippocampal network function. Front. Synaptic Neurosci. 5:2. doi: $10.3389 /$ fnsyn. 2013.00002

Tsubokawa, H. (2000). Control of Na+ spike backpropagation by intracellular signaling in the pyramidal neuron dendrites. Mol. Neurobiol. 22, 129-141. doi: 10.1385/MN:22:1-3:129

Tsubokawa, H., and Ross, W. N. (1997). Muscarinic modulation of spike backpropagation in the apical dendrites of hippocampal CA1 pyramidal neurons. J. Neurosci. 17, 5782-5791.

Turrini, P., Casu, M. A., Wong, T. P., De, K. Y., Ribeiro-Da-Silva, A., and Cuello, A. C. (2001). Cholinergic nerve terminals establish classical synapses in the rat cerebral cortex: synaptic pattern and age-related atrophy. Neuroscience 105, 277-285. doi: 10.1016/S0306-4522(01)00172-5

Umbriaco, D., Garcia, S., Beaulieu, C., and Descarries, L. (1995). Relational features of acetylcholine, noradrenaline, serotonin and GABA axon terminals in the stratum radiatum of adult rat hippocampus (CA1). Hippocampus 5, 605-620. doi: 10.1002/hipo.450050611

Umbriaco, D., Watkins, K. C., Descarries, L., Cozzari, C., and Hartman, B. K. (1994). Ultrastructural and morphometric features of the acetylcholine innervation in adult rat parietal cortex: an electron microscopic study in serial sections. J. Comp. Neurol. 348, 351-373. doi: 10.1002/cne.903480304

Vizi, E. S., Fekete, A., Karoly, R., and Mike, A. (2010). Non-synaptic receptors and transporters involved in brain functions and targets of drug treatment. Br. J. Pharmacol. 160, 785-809. doi: 10.1111/j.1476-5381.2009.00624.x

Widmer, H., Ferrigan, L., Davies, C. H., and Cobb, S. R. (2006). Evoked slow muscarinic acetylcholinergic synaptic potentials in rat hippocampal interneurons. Hippocampus 16, 617-628. doi: 10.1002/hipo.20191

Wu, J., Kuo, Y. P., George, A. A., Xu, L., Hu, J., and Lukas, R. J. (2004). beta-Amyloid directly inhibits human alpha4beta2-nicotinic acetylcholine receptors heterologously expressed in human SH-EP1 cells. J. Biol. Chem. 279, 37842-37851. doi: 10.1074/jbc.M400335200

Zhang, H., Lin, S. C., and Nicolelis, M. A. (2010). Spatiotemporal coupling between hippocampal acetylcholine release and theta oscillations in vivo. J. Neurosci. 30, 13431-13440. doi: 10.1523/JNEUROSCI.1144-10.2010

Conflict of Interest Statement: The author declares that the research was conducted in the absence of any commercial or financial relationships that could be construed as a potential conflict of interest.

Received: 14 July 2014; accepted: 29 August 2014; published online: 16 September 2014. Citation: McQuiston AR (2014) Acetylcholine release and inhibitory interneuron activity in hippocampal CA1. Front. Synaptic Neurosci. 6:20. doi: 10.3389/fnsyn. 2014.00020

This article was submitted to the journal Frontiers in Synaptic Neuroscience.

Copyright (C) 2014 McQuiston. This is an open-access article distributed under the terms of the Creative Commons Attribution License (CC BY). The use, distribution or reproduction in other forums is permitted, provided the original author(s) or licensor are credited and that the original publication in this journal is cited, in accordance with accepted academic practice. No use, distribution or reproduction is permitted which does not comply with these terms. 